\title{
PENYESUAIAN SOSIAL SISWA TUNA RUNGU DI SEKOLAH UMUM : STUDI KASUS
}

\author{
Dian Rachmawati Wasito, Dwi Sarwindah, Wiwik Sulistiani \\ Fakultas Psikologi Universitas Hangtuah Surabaya \\ e-mail:wie_ko2@yahoo.com
}

\begin{abstract}
Hearing impaired students generally study with other students who have the same special need in special schools called Sekolah Luar Biasa B (SLB B). However, inclusive education which enables students with special need to study in the same classes with normal students has been developing rapidly in recent years in Indonesia. This study aimed at investigating the social adjustment of hearing impaired students who study with normal students in a general school. A qualitative approach with case study method was employed. Participants of the study were three hearing impaired students and three significant others of each student who were their parents, teachers dan close friends. Data were analysed using a thematic analysis. This study found that participants socially adjusted in effective ways during their studies with normal students in the general school.
\end{abstract}

Key words: hearing impaired students, social adjustment, general school

\begin{abstract}
Abstrak: Siswa tuna rungu pada umumnya belajar dengan siswa lain yang memiliki kebutuhan khusus serupa di sekolah-sekolah khusus yang disebut Sekolah Luar Biasa B (SLB B). Namun pendidikan inklusif yang memungkinkan siswa dengan kebutuhan khusus untuk belajar di kelas yang sama dengan siswa normal telah berkembang pesat dalam beberapa tahun terakhir di Indonesia. Penelitian ini bertujuan untuk mengkaji penyesuaian sosial siswa tuna rungu yang belajar dengan siswa normal di sekolah umum. Pendekatan kualitatif dengan metode studi kasus digunakan dalam penelitian ini. Partisipan penelitian adalah tiga siswa tuna rungu dan tiga orang lain yang signifikan bagi setiap siswa, yakni orang tua mereka, guru dan teman dekat mereka. Data dianalisis menggunakan analisis tematik. Studi ini menemukan bahwa partisipan menyesuaikan diri dengan cara-cara yang efektif selama masa studi mereka dengan siswa normal di sekolah umum.
\end{abstract}

Kata kunci: Penyesuaian sosial, siswa tuna rungu, sekolah umum

Jumlah penderita cacat fisik maupun mental di Indonesia cukup besar. Hasil analisa Badan Pusat Statistik dan Departemen Sosial tahun 2003 menjelaskan bahwa jumlah penyandang cacat di Indonesia sekitar 1,48 juta atau 0,7 persen dari jumlah penduduk. Jumlah penyandang cacat umur 5-18 tahun atau masuk kategori usia sekolah diprediksi 21,42 persen dari seluruh penyandang cacat yaitu sekitar 317.016 anak (Jawa Pos, 2007). Kategori kecacatan terbagi dalam beberapa jenis yakni tuna netra, tuna rungu, tuna grahita, tuna daksa, tuna laras, tuna ganda dan autis. Kelompok yang digolongkan berdasarkan adanya gangguan pada pendengaran disebut dengan tuna rungu.

Anak tuna rungu dengan keterbatasannya juga berhak mendapatkan pendidikan seperti anak lainnya. Tempat anak tuna rungu memperoleh pendidikan disebut dengan SLB B. Sekolah tersebut menerapkan kurikulum khusus bagi anak dan remaja dengan gangguan pendengaran yang berbasiskan kompetensi berbahasa dan komunikasi untuk menuju kecakapan hidup. Dalam perkembangan terbaru di Indonesia, ada beberapa sekolah umum yang mau menerima anak penderita tuna rungu. Departemen Pendidikan dan Kebudayaan (1977) memang mengeluarkan kebijakan program integrasi, yakni sekolah umum bisa menerima anak atau remaja berkebutuhan khusus dengan ketentuan tertentu yang telah dipenuhi. Sekolah yang menerapkan program integrasi ini disebut sekolah inklusi.

Sekolah inklusi menyediakan guru pembimbing khusus, sarana belajar yang dapat diakses siswa yang memiliki kebutuhan 
khusus seperti alat bantu dengar dan buku berhuruf braile, dan sarana dan prasarana sekolah yang mendukung ruang gerak serta kurikulum yang lebih fleksibel. Namun, keberadaan sekolah inklusi belum mampu memenuhi kebutuhan pendidikan seluruh anak tuna rungu. Hal tersebut terjadi karena banyaknya jumlah anak tuna rungu sehingga membuat anak tuna rungu lebih memilih untuk bersekolah di sekolah umum biasa dengan ketentuan dan fasilitas yang terbatas. Padahal sekolah umum cenderung hanya menyediakan sarana belajar standar untuk siswa normal dan kurang memberi fasilitas atau sarana yang dapat diakses siswa berkebutuhan khusus termasuk siswa tuna rungu.

Karena itu dapat diasumsikan bahwa anak tuna rungu di sekolah umum akan berpotensi menghadapi berbagai permasalahan dalam belajar maupun interaksi sosial. Salah satu permasalahan yang dihadapi oleh penderita tuna rungu adalah adanya keterbatasan yang terkait dengan proses komunikasi dan sosialisasi. Anak tuna rungu juga akan cenderung mengalami masalah dalam hal mereka tidak mempunyai kemampuan berbahasa yang wajar padahal bahasa merupakan prasyarat dari kemampuan kognisi. Karena itu anak tuna rungu kemungkinan akan mengalami kesulitan dalam berfikir (Delphie, 2006:108). Anak tuna rungu yang bersekolah di sekolah umum kemungkinan besar juga akan menghadapi kesulitan dalam bersosialisasi karena keterbatasan dalam berkomunikasi tersebut. Terutama anak tuna rungu akan mengalami kesulitan mengikuti petunjuk lisan, berpartisipasi dalam kegiatan oral, dan hambatan dalam perkembangan bahasa (Delphie, 2006:103).

Anak tuna rungu juga akan tumbuh menjadi seorang remaja. Remaja tuna rungu memiliki tugas perkembangan yang sama dengan remaja normal yaitu melakukan penyesuaian diri dan sosial. Masa remaja merupakan periode perkembangan psiko- fisiologis yang dialami hampir semua individu pada rentang usia 12 hingga 21 tahun. Adanya tugas perkembangan untuk pemenuhan penyesuaian diri pada lingkungan sosial tentu membutuhkan usaha yang lebih besar bagi remaja tuna rungu.

Sekolah merupakan tempat anak dan remaja tuna rungu belajar berkomunikasi dan bersosialisasi serta mengembangkan potensi yang dimilikinya. Remaja tuna rungu akan memerlukan penyesuaian diri yang baru ketika berada di lingkungan yang baru. Permasalahan akan muncul ketika remaja tuna rungu berada dalam satu tempat dengan anak rnormal di sekolah umum. Selama ini, permasalahan yang dialami penderita tuna rungu adalah kesulitan dalam melakukan komunikasi, dan karena itu juga kemungkinan besar berimplikasi negatif pada kemampuan penyesuaian dirinya.

Hurlock (1980:287) mengartikan penyesuaian sosial sebagai keberhasilan individu dalam menyesuaikan diri dengan orang lain. Orang yang dapat menyesuaikan diri dengan baik berarti telah mempelajari berbagai keterampilan-keterampilan sosial seperti kemampuan untuk menjalin hubungan diplomatis dengan orang lain baik teman maupun orang yang tidak dikenal. Tidak semua orang mampu melakukan penyesuaian sosial dengan baik terhadap lingkungan. Banyak individu yang kurang dapat menyesuaikan diri secara sosial maupun pribadi. Adapun faktor-faktor yang mempengaruhi penyesuaian sosial yaitu kematangan emosi dan teman (Hurlock, 1980: $233,288)$.

Hurlock (1980:287) menjelaskan bahwa kriteria penyesuaian sosial yaitu: pertama, penampilan nyata. Bila perilaku sosial anak, seperti yang dinilai berdasarkan standar kelompok, memenuhi harapan kelompok, anak akan menjadi anggota kelompok yang akan diterima kelompok. Kedua, penyesuaian diri terhadap berbagai kelompok. Anak yang saat menyesuaikan diri dengan baik terhadap berbagai kelompok baik 
kelompok sebaya maupun kelompok orang dewasa secara sosial dianggap sebagai orang yang dapat menyesuaikan diri dengan baik. Ketiga, sikap sosial. Anak harus yang menunjukkan sikap yang menyenangkan terhadap orang lain, terhadap partisipasi sosial, dan terhadap peran terhadap kelompok sosial, bila ingin dinilai sebagai orang yang dapat menyesuaikan diri dengan baik secara sosial. Keempat, kepuasan pribadi. Untuk dapat menyesuaikan diri dengan baik secara sosial, anak harus merasa puas terhadap kontak sosial dan terhadap peran dimainkan dalam situasi sosial, baik sebagai pemimpin maupun sebagai anggota.

Adapun kriteria penyesuaian diri di lingkungan sekolah meliputi beberapa kriteria menurut Scheneider (1964:454), yaitu: pertama, menghargai dan menerima otoritas sekolah, peraturan sekolah, kepala sekolah, dan guru. Kedua, berminat dan berpartisipasi dalam aktivitas sekolah, mau melibatkan diri dalam pada kegiatan-kegiatan yang diadakan oleh sekolah serta adanya keinginan dalam melibatkan diri dalam aktivitas tersebut. Ketiga, membina relasi sosial yang sehat dan bersahabat dengan teman sekelas, guru dan penasihat sekolah. Keempat, mau menerima tanggung jawab serta batasan-batasan yang dibuat oleh sekolah. Kelima, membantu sekolah dalam mewujudkan tujuan.

Effendi (2006:83) menjelaskan bahwa terganggunya pendengaran seseorang menyebabkan terbatasnya penguasaan bahasa. Hal ini dapat menghambat kesempatan untuk berkomunikasi dengan lingkungan sosial. Berangkat dari kondisi demikian, seseorang dengan keterbatasan dalam kemampuan pendengarannya seringkali tampak frustasi. Akibat yang muncul, penderita tuna rungu sering menampakkan sikap-sikap asosial, bermusuhan, atau menarik diri dari lingkungannya. Keadaan ini semakin tidak menguntungkan ketika beban ditambah dengan sikap lingkungan atau tekanan lain yang berasal dari luar diri (teman sebaya, keluarga, masyarakat sekitar) yang berupa cemooh, ejekan, dan bentuk penolakan lain yang sejenis. Hal ini tentu membuat anak tuna rungu akan semakin merasa tidak aman, bimbang dan ragu-ragu terhadap keberadaan dirinya.

Berdasarkan hasil observasinya yang dilakukan secara berkelanjutan, Van uden (dalam Effendi, 2006:84) berhasil mencatat beberapa sifat kepribadian anak tuna rungu yang berbeda dengan anak normal, antara lain: 1) anak tuna rungu lebih egosentris; 2) anak tuna rungu lebih tergantung pada orang lain dan apa-apa yang sudah dikenal; 3) perhatian anak tuna rungu lebih sukar dialihkan; 4) anak tuna rungu lebih memperhatikan yang konkret; 5) anak tuna rungu lebih miskin dalam fantasi; 6) anak tuna rungu umumnya mempunyai sifat polos, sederhana, tanpa banyak masalah; 7) perasaan anak tuna rungu lebih cenderung dalam keadaan ekstrem tanpa banyak nuansa; 8) anak tuna rungu lebih mudah marah dan lekas tersinggung; 9) anak tuna rungu kurang mempunyai konsep tentang hubungan; 10) anak tuna rungu mempunyai perasaan takut akan hidup yang lebih besar.

Adanya lingkungan yang berbeda, dalam hal belajar bersama siswa-siswa normal di sekolah umum, tentu menimbulkan masalah baru bagi remaja tuna rungu. Pendengaran yang terganggu menyebabkan terbatas dalam penguasaan bahasa. Hal ini dapat menghambat kesempatan untuk berkomunikasi dengan lingkungan sosialnya. Berdasarkan permasalahan ini, peneliti ingin mengungkap dan mengkaji lebih dalam bagaimana penyesuaian sosial remaja tuna rungu yang belajar di sekolah umum. Penelitian ini penting untuk dilakukan karena dapat memberikan pemahaman yang mendalam tentang kondisi psikososial remaja tuna rungu yang belajar di sekolah umum. Selain itu, hasil penelitian ini dapat digunakan sebagai informasi awal untuk membantu meningkatkan kemampuan akademik maupun sosial anak tuna rungu di sekolah umum. 


\section{METODE}

Penelitian ini menggunakan pendekatan kualitatif deskriptif dengan metode studi kasus untuk mengkaji secara mendalam penyesuaian sosial remaja tuna rungu yang bersekolah di sekolah umum. Fokus penelitian dalam penelitian ini adalah apakah para siswa tuna rungu melakukan hal-hal sebagai berikut: pertama, menghargai dan menerima otoritas sekolah, peraturan sekolah, kepala sekolah, dan guru; kedua, berminat dan berpartisipasi dalam aktivitas sekolah, mau melibatkan diri dalam pada kegiatan-kegiatan yang diadakan oleh sekolah serta adanya keinginan dalam melibatkan diri dalam aktivitas tersebut; ketiga, membina relasi sosial yang sehat dan bersahabat dengan teman sekelas, guru dan penasihat sekolah; keempat, mau menerima tanggung jawab serta batasan-batasan yang dibuat oleh sekolah; kelima, membantu sekolah dalam mewujudkan tujuan; keenam, menunjukkan penampilan (performance) nyata yang baik; ketujuh, melakukan penyesuaian diri terhadap berbagai kelompok; kedelapan, menunjukkan sikap sosial yang cukup baik; dan kesembilan, memperlihatkan kepuasan pribadi.

\section{Partisipan}

Subjek penelitian penelitian ini adalah siswa tuna rungu yang belajar di SMK Negeri 8 Surabaya. Proses pemilihan subjek selaku informan inti dilakukan melalui tahap pengisian kuesioner sederhana yang menggunakan kategori menurut Hurlock (1980: 287) yaitu: penampilan nyata, penyesuaian terhadap berbagai kelompok, sikap sosial, dan kepuasan diri. Setelah menganalisis hasil kuesioner yang diisi 7 siswa tuna rungu, diambil 3 subjek yang berusia 17 hingga 18 tahun, berasal dari keluarga menengah, tidak menggunakan alat pendengaran, serta memiliki penyesuaian sosial di sekolah dan kepuasan pribadi yang cukup baik.

\section{Teknikpengumpulan data}

Penelitian ini mengggunakan dua teknik pengambilan data yaitu wawancara dan observasi kelas. Data wawancara tidak hanya diperoleh dari ketiga subjek yang memenuhi kriteria. Data penunjang juga diperoleh dari hasil wawancara guru, orang tua, dan teman dari masing-masing subjek selaku significant others. Sedangkan observasi yang digunakan dalam penelitian ini adalah observasi dalam bentuk rating scale. Ketiga subjek yang telah dipilah akan diobservasi selama 7 hari di dalam kelas, selain itu ketiga subjek juga akan di wawancarai 3 hingga 4 kali untuk menggali informasi terkait penyesuaian sosial remaja tuna rungu yang bersekolah di sekolah umum.

\section{Teknik analisis data}

Teknik analisis yang digunakan dalam penelitian ini adalah teknik analisis tematik. Sementara kredibilitas dalam penelitian ini disandarkan pada triangulasi data dan teori. Uji transferabilitas dapat dipertanggungjawabkan melalui prosedur pengambilan sampel yang diarahkan pada unit-unit esensial dan tipikal dari karakteristik subjek yang diteliti, dan juga melalui unit-unit teoritis yang digunakan sesuai dengan pemahaman konseptual terhadap subjek atau topik yang diteliti. Selain itu, uji dependabilitas yang digunakan adalah keterbukaan peneliti dalam memanfaatkan metode-metode yang berbeda untuk mencapai tujuan yaitu menggunakan metode wawancara dan observasi dan diskursus, yakni sejauh mana dan seintensif apa peneliti mendiskusikan temuan analisis dengan orang lain.

\section{HASIL DAN PEMBAHASAN}

Berdasarkan data yang telah didapatkan oleh peneliti, antara ketiga subjek terdapat beberapa perbedaan terkait cara subjek dalam melakukan penyesuaian sosial di sekolah. Perbedaan tersebut dipengaruhi beberapa faktor yang salah satunya adalah dukungan orang tua. Ketiga subjek Y, A, dan F 
mendapatkan dukungan dari orang tua. Walaupun kapasitas setiap anak berbeda namun adanya dukungan dari keluarga membantu proses penyesuaian sosial yang efisien.

Pada Y, dukungan yang diberikan oleh orang tua adalah perhatian yang diberikan dalam bentuk pertanyaan tentang aktivitas dan kegiatan yang dilakukan setiap hari. Ibu subjek juga mencari tahu apabila ada masalah yang dimiliki. Ibu subjek tidak mampu mengikuti perkembangan subjek secara mendetail karena orang tua juga harus bekerja. Ibu Y ikut serta dalam mengawasi perkembangan subjek saat pertama kali masuk sekolah dan berusaha mencari informasi tentang hal yang harus dilakukan $\mathrm{Y}$ saat pertama kali masuk sekolah.

Subjek A mendapatkan dukungan berupa perhatian penuh dan kepercayaan. Ibu subjek A juga sangat memperhatikan perkembangan bakat dan minat subjek. Ibu subjek A fokus memberikan dukungan terhadap perkembangan A karena ibu Aadalah ibu rumah tangga. Perhatian yang juga diberikan oleh ibu A adalah membiasakan anak untuk menceritakan masalah setiap hari dan meningkatkan kepercayaan diri subjek dengan melihat kelebihan yang dimiliki.

Subjek F mendapatkan dukungan berupa perhatian. Orang tua subjek selalu berusaha untuk menghilangkan rasa rendah diri yang dirasakan subjek dengan cara bekerja sama dengan wali kelas untuk memantau perkembangan $\mathrm{F}$ dan mencarikan teman untuk mau menemani F. F juga dibiasakan untuk menceritakan segala aktivitas setiap malam dan masalah apa yang terjadi pada saat di sekolah.

Dukungan yang diberikan pada setiap subjek berbeda dan hal ini mempengaruhi proses penyesuaian sosial mereka. Hal ini dapat dimengerti karena sifat hubungan yang terjadi antara anak dengan orang tua pada tahun-tahun pertama kehidupan akan menentukan corak hubungan antara anak dengan lingkungan sosial sekitar di kemudian hari (Effendi, 2006:83-84).

Pembahasan selanjutnya akan mencermati penyesuaian sosial para subjek penelitian berdasarkan sembilan kategori yang menjadi fokus penelitian, yaitu: menghargai dan menerima otoritas, minat dan partisipasi dalam kegiatan sekolah, menjalin relasi sosial, tanggung jawab, ikut mewujudkan tujuan sekolah, penampilan nyata, penyesuaian diri terhadap kelompok, sikap sosial, dan kepuasan pribadi.

\section{Menghargai dan menerima otoritas}

Para subjek sama-sama menghargai dan menerima otoritas sekolah, peraturan sekolah, kepala sekolah, dan guru. Mereka memiliki keasamaan dalam mengenal peraturan yang sederhana dalam bentuk peraturan tertulis namun kurang memahami adanya peraturan tidak tertulis. Y, A, dan $\mathrm{F}$ mengenal bahwa peraturan yang ada di sekolah seperti tidak boleh terlambat, memakai seragam, dilarang merokok, dilarang membolos sedangkan untuk peraturan tertulis, $\mathrm{Y}, \mathrm{A}$, dan $\mathrm{F}$ menjelaskan bahwa peraturan selain peraturan yang dijelaskan di atas adalah tidak ada karena peraturan yang ada hanya yang telah disebutkan diatas sama seperti anak yang lain. Adanya pemahaman tentang pengetahuan sederhana dan kurang pemahaman atas peraturan tidak tertulis disebabkan karena kehilangan pendengaran yang menyebabkan miskin kosakata, sulit mengartikan kata kiasan (Sutjiati, 2006:100).

Ketiga subjek memang terbatas dalam hal bahasa namun subjek Y, A, dan F termasuk anak yang mampu menghargai guru dan kepala sekolah serta taat pada peraturan yang dibuat oleh guru dikelas. Hal tersebut ditunjukkan bahwa ketiga subjek tidak pernah mendapatkan teguran keras baik dari guru maupun kepala sekolah. Y, A, dan F mampu mengikuti pelajaran dengan tertib dan taat pada peraturan selama di dalam kelas. Peraturan yang kemungkinan dilanggar oleh ketiga subjek adalah terlambat sekolah dan 
mengobrol di sekolah. Perilaku yang ditampilkan Y, A, dan F menunjukkan bahwa ketiga subjek mampu menerima norma yang dibuat oleh lingkungan sekolah sedangkan anak tuna rungu seringkali mengalami hambatan sehingga sulit menerima norma di lingkungan.

\section{Minat dan partisipasi dalam kegiatan sekolah}

Secara teoritis, adanya gangguan pendengaran pada seseorang menyebabkan keterbatasan dalam penguasaan bahasa sehingga kesempatan untuk berkomunikasi dengan lingkungan sosialnya akan terhambat. Karena itu seseorang yang terganggu pendengarannya seringkali tampak frustasi dan akhirnya sering menampakkan sikapsikap asosial seperti bermusuhan atau menarik diri dari lingkungan (Effendi, 2006:83). Ketiga subjek tidak menampakkan hal-hal seperti dijelaskan dalam pernyataan di atas. Y, A, dan F berminat dalam aktivitas sekolah. Adanya gangguan pendengaran tidak membuat ketiga subjek merasa malu untuk ikut serta dalam aktivitas sekolah. Y, A, dan F memang tidak mengikuti kegiatan organisasi yang diadakan sekolah karena keterbatasan dalam berkomunikasi namun ketiga subjek tidak menarik diri. A, Y, dan F mengikuti kegiatan sekolah yang mungkin dapat diikuti seperti kegiatan ekstrakurikuler yaitu basket dan berenang. Ketiga subjek mengikuti kegiatan tersebut dengan cara memperhatikan gerakan yang dipraktekkan guru atau teman dan mengikuti latihan secara rutin.

\section{Menjalin relasi sosial}

Penyesuaian sosial juga dikatakan efektif apabila mampu membina hubungan antar pribadi yang baik (Haber dan Ruyon, 1984:25). Proses membina hubungan antar pribadi yang baik masuk dalam satu kategori penyesuaian sosial di sekolah yaitu mampu membina relasi sosial yang sehat dan bersahabat dengan teman sekelas, guru dan perangkat sekolah. Kemampuan subjek dalam membina relasi sosial berbeda satu sama lain.
Subjek Y dan A mampu membina hubungan pribadi yang baik dengan teman dan guru sedangkan $\mathrm{F}$ kurang mampu membina hubungan pribadi yang baik karena masih terbatas dalam hal berkomunikasi. F lebih sering menyendiri dan terkucilkan ketika di kelas. Hubungan $\mathrm{F}$ dengan guru dan teman sulit karena merasa terhambat untuk berkomunikasi. F sering terkucilkan karena kurang memahami hal yang dibicarakan teman dan mengeluarkan suara keras ketika diajak bicara dan kurang menunjukkan respon ketika diajak bicara. Y merasa diperlakukan buruk yaitu seringkali diganggu dan dipaksa melakukan pekerjaan yang tidak ingin $Y$ lakukan oleh teman dikelas namun subjek mampu berteman dengan beberapa teman dekat yang mau menerima keterbatasan. A dan $F$ diperlakukan baik di lingkungan kelas mereka. A mampu membina relasi sosial yang sehat dan bersahabat dengan teman sekelas namun A tertutup dan tidak mau menceritakan masalah pada teman dekat. A hanya mau menceritakan semua masalah pada ibu dan bukan pada teman.

Setiap subjek memiliki hambatan tersendiri dalam membina hubungan pribadi yang baik namun ketiga subjek berusaha untuk mampu bersikap sopan dan menghargai guru dan kepala sekolah. Y, A, dan F mau memberi salam dan mencium tangan ketika bertemu dengan guru atau kepala sekolah. Ketiga subjek mau mendengarkan perintah guru dan tertib pada saat di kelas. Ketiga subjek juga berusaha untuk mengembangkan kemampuan berkomunikasi dengan cara berbicara dengan bahasa biasa dan memperjalas dalam bentuk tulisan apabila proses pembicaraan sulit dimengerti. Ketiga subjek juga berusaha untuk berinteraksi dengan teman di kelas.

\section{Tanggungjawab}

Sebagai seorang siswa, ketiga subjek wajib menerima tanggung jawab serta batasan-batasan yang dibuat oleh sekolah. Sekolah memiliki cara tersendiri untuk 
mengenalkan peraturan sekolah yaitu dengan cara memberikan edaran untuk orang tua sehingga siswa tuna rungu mendapatkan perlakukan yang sama seperti siswa yang lain. $\mathrm{Y}$, A, dan $\mathrm{F}$ merupakan siswa dengan gangguan pendengaran dan seperti yang diketahui bahwa anak tersebut mengalami hambatan sehingga sulit menerima norma lingkungan. Adanya penjelasan di atas diperoleh bahwa anak tuna rungu seringkali sulit menerima norma yang ada karena kurang dikenalkan oleh lingkungan. Di sekolah umum, ketiga subjek di perlakukan sama dengan siswa lain yaitu diberi surat edaran sehingga mampu mengetahui peraturan yang berlaku di sekolah. Hal tersebut ditunjukkan bahwa ketiga subjek tidak pernah melanggar peraturan sekolah seperti tidak membolos sekolah. Pelanggaran yang mungkin dilakukan oleh ketiga subjek adalah terlambat sekolah. Ketiga subjek mampu menerima dan melaksanakan norma dan aturan yang ada di sekolah.

Proses penyesuaian sosial dapat dilihat melalui tingkat kematangan sosial individu sedangkan penerimaan nilai sosial bagi anak tuna rungu merupakan jembatan dalam pengembangan kematangan sosial. Siregar (dalam Effendi, 2006:83) berpendapat untuk mencapai kematangan sosial, anak tuna rungu paling tidak memiliki pengetahuan yang cukup mengenai nilai-nilai sosial dan kebiasaan di masyarakat dan mempunyai kesempatan yang banyak untuk menerapkan pengetahuan-pengetahuan tersebut (Effendi, 2006: 83). Adanya informasi dari sekolah membuat ketiga subjek berusaha untuk mematuhi peraturan yang ada. Adanya pelanggaran yang terjadi pada subjek seringkali disebabkan oleh kesalahpahaman menerima informasi seperti adanya informasi terkait dengan pengumuman yang hanya dibicarakan dari mulut ke mulut yang kemudian tidak didengar oleh ketiga subjek. Pelanggaran yang biasa dilakukan oleh ketiga subjek adalah terlambat sekolah. Proses pelaksanaan peraturan diterapkan melalui dua cara yaitu patuh pada peraturan yang ikut serta untuk mencegah terjadi pelanggaran. Ketiga subjek dengan keterbatasan lebih banyak menunjukkan diam ketika melihat teman yang melakukan pelanggaran namun tidak dengan subjek Y. Y mampu menegur teman yang melakukan perilaku pelanggaran. Sikap diam oleh subjek A dan F disebabkan oleh sifat salah satu penderita tuna rungu yaitu polos, sederhana, dan tanpa banyak masalah (Effendi, 2006:84).

\section{Ikut mewujudkan tujuan sekolah}

Setiap siswa di sekolah juga ikut berperan dalam mewujudkan tujuan sekolah termasuk siswa tuna rungu. Cara yang dapat dilakukan oleh ketiga subjek selaku siswa tuna rungu adalah hampir sama. Ketiga subjek menunjukkan kebanggaan sebagai siswa SMK Negeri 8 Surabaya. Ketiga subjek tetap merasa senang dan mau berusaha untuk diterima di lingkungan walaupun pada subjek Y mengalami penerimaan sosial kelas yang buruk yaitu sering diganggu dan dipaksa oleh teman dan $\mathrm{F}$ yang merasa terkucilkan karena kesulitan dalam berkomunikasi ketika di dalam kelas. Upaya perwujudan sekolah dapat dilakukan berbagai cara seperti berprestasi di kelas, tidak melakukan pelanggaran yang dapat menyebabkan membawa nama buruk sekolah, dan menunjukkan mampu berprestasi membawa nama baik sekolah. Pencapaian kematangan sosial yang merupakan salah satu syarat yang harus dimiliki oleh setiap individu dalam penyesuaian sosial yaitu dengan cara cukup mendapatkan kesempatan mengalami berbagai macam bentuk hubungan sosial dan mempunyai dorongan untuk mencari pengalaman di atas (Effendi, 2006:83).

Y, A, dan F sebagai siswa yang memiliki keterbatasan berusaha untuk melakukan hal yang bisa dilakukan. Ketiga subjek berusaha untuk mencari pengalaman dalam bentuk hubungan sosial dengan lingkungan sekolah. Ketiga subjek berusaha menunjukkan bahwa Y, A, dan F ikut serta dalam mewujudkan tujuan sekolah. $\mathrm{Y}$ berusaha berprestasi pada 
pelajaran yang disukai dan pelajaran yang dianggap mudah oleh subjek adalah pelajaran yang lebih mengutamakan praktek namun belum mampu mengikuti lomba untuk mewakili sekolah. A berusaha menjaga sikap dengan cara tidak melakukan pelanggaran sekolah ketika menggunakan seragam, memiliki nilai yang cukup baik dalam pelajaran yang disukai yaitu matematika dan kewarganegaraan namun tidak mau mewakili sekolah untuk mengikuti lomba karena tidak ingin mencampuradukkan urusan pendidikan dengan hobi A di bidang modeling. F mampu memiliki nilai cukup baik pada pelajaran matematika, tidak melakukan pelanggaran sekolah namun belum pernah dikirim lomba untuk mewakili sekolah.

\section{Penampilan nyata}

Setiap siswa berusaha untuk memberikan penampilan nyata yang baik terhadap lingkungan sekolah. Hal ini dilakukan sebagai upaya siswa untuk mampu diterima di lingkungan sekolah baik oleh guru maupun teman. Penampilan nyata yang baik dapat dilihat baik apabila perilaku sosial anak yang dinilai berdasarkan standar kelompok, memenuhi harapan kelompok, anak akan menjadi anggota kelompok yang akan diterima kelompok (Hurlock, 1980:287). Penampilan nyata yang diberikan ketiga subjek pada teman adalah mau membantu teman walaupun hanya memberikan bantuan sederhana seperti memberi pinjaman buku, membeli makanan di kantin atau piket kelas. Ketiga subjek juga berusaha untuk berinteraksi dengan teman tanpa malu dengan keterbatasan dan mampu berdiskusi dengan teman. A dan Y mampu menampilkan sikap ramah pada siswa di luar dan dalam kelas yaitu mau tersenyum ketika bertemu teman luar kenal di jalan. Ketiga subjek mampu membina hubungan antar pribadi yang baik dan memiliki konsep diri yang positif yang merupakan bagian dari faktor penyesuaian sosial yang efektif (Haber dan Ruyon, 1984: 25).
Penampilan nyata pada teman juga dilihat melalui cara subjek dalam menghadapi teman yang marah. Y tidak pernah marah pada teman walaupun teman di kelas bersikap sewenang-wenang. Sikap yang ditampilkan $\mathrm{Y}$ adalah hanya menggerutu, A tidak pernah marah namun mau memberikan perlawanan apabila teman bersikap sewenang-wenang, $F$ tidak pernah marah pada teman namun lebih sering dimarahi karena sering salah paham dan respon subjek F adalah diam. Salah satu faktor yang mempengaruhi penyesuaian sosial adalah emosi. Emosi memainkan peran penting dalam menentukan cara penyesuaian pribadi dan sosial yang akan dilakukan anak, tidak hanya dalam masa kanak-kanak tetapi juga setelah mereka tumbuh tumbuh menjadi remaja dan dewasa maka perkembangan emosi individu harus sedemikian rupa sehingga memungkinkan penyesuaian yang baik (Hurlock, 1980: 233). Bentuk emosi yang ditampilkan ketiga subjek berbeda-beda dan penyaluran emosi yang berlebihan tidak muncul walaupun lingkungan tidak memahami keadaan subjek. Ketiga subjek mampu menekan emosi ketika menghadapi perasaan marah dan berusaha memberikan ekspresi emosi positif.

Penampilan nyata juga ditunjukkan pada guru, kepala sekolah dan lingkungan sekolah. Kematangan sosial merupakan salah satu satu syarat yang harus dimiliki oleh setiap individu dalam penyesuaian sosial dan kematangan anak tuna rungu diharapkan memiliki yaitu cukup mendapatkan kesempatan mengalami berbagai macam bentuk hubungan sosial dan mempunyai dorongan untuk mencari pengalaman (Effendi, 2006:83). Y, A, dan F berusaha untuk membina hubungan sosial yang baik dengan guru dengan cara bersikap sopan pada guru yang ada di kelas, bersikap baik dengan cara memberi salam ketika bertemu kepala sekolah. Cara yang dilakukan oleh ketiga subjek adalah mampu mendengarkan perintah guru dan bersikap ramah terhadap guru ketika di kelas seperti dengan cara berusaha untuk tetap tenang ketika di 
kelas, memperhatikan ketika guru mendengarkan, melaksanakan tugas dari guru yang bersangkutan dan mau menjawab ketika diajak berbicara oleh guru.

\section{Penyesuaian terhadap kelompok}

Proses membina hubungan sosial di sekolah membutuhkan penyesuaian diri terhadap kelompok. Anak yang mampu melakukan penyesuaian diri yang baik terhadap kelompok baik kelompok sebaya maupun dewasa secara sosial dianggap sebagai orang yang dapat menyesuaikan diri dengan baik (Hurlock, 1980: 287). Proses penyesuaian diri terhadap kelompok dilakukan ketiga subjek dengan cara berbeda. Y dan A akan cuek dan diam ketika lingkungan kurang menyukai sedangkan $\mathrm{F}$ berusaha mendapatkan teman lain ketika ada teman tidak menyukai subjek. A tidak sama seperti Y dan F ketika menghadapi masalah. A mau memberikan perlawanan diri apabila merasa teman berlaku sangat sewenag-wenang sedangkan $\mathrm{Y}$ dan $\mathrm{F}$ hanya diam. Berdasarkan sifat dan kepribadian anak tuna rungu menunjukkan bahwa anak tuna rungu mempunyai sifat polos, sederhana dan tanpa banyak masalah (Effendi, 2006:84). Ketiga subjek memilih diam atau berusaha untuk mencari jalan lain dari pada mempermasalahkan keadaan lingkungan yang dianggap kurang menghargai subjek namun selama ini ketiga subjek masih diperlakukan cukup baik dari lingkungan sekolah. Bentuk penyesuaian diri terhadap teman yang juga dilakukan oleh ketiga subjek adalah mau meminta maaf ketika melakukan sebuah kesalahan.

Proses penyesuaian diri terhadap kelompok juga dapat dilihat melalui kegiatan di kelas yaitu proses kerja kelompok. Ketiga subjek selalu bekerja kelompok dengan teman dekat yang mau membantu. Ketiga subjek berkelompok dengan teman yang sama yang mau menerima keterbatasan dan serta dapat membantu mengajarkan ketika ada tugas kelompok. Berdasarkan salah satu sifat kepribadian anak tuna rungu adalah lebih tergantung pada orang lain dan apa-apa yang sudah dikenal (Effendi, 2006:84). Y, A, dan F berusaha bekerja sama dengan teman dalam melakukan tugas kelompok. Ketiga subjek akan melakukan tugas yang mungkin mampu dikerjakan oleh subjek seperti mengetik, menulis dan lain-lain. Proses pemilihan kelompok dari ketiga subjek terjadi perbedaan. A dan F mampu memilih anggota kelompok secara mandiri sedangkan Y dipilihkan oleh guru subjek. Hal ini terjadi karena tidak semua teman subjek Y mau menerima keterbatasan subjek. Adanya sikap lingkungan atau tekanan lain yang berasal dari luar diri (teman sebaya, keluarga, masyarakat sekitar) yang berupa cemooh, ejekan, dan bentuk penolakan lain yang sejenis dan berdampak negatif. Hal ini tentu membuat anak tuna rungu semakin tidak aman, bimbang dan ragu-ragu terhadap keberadaan diri penderita tuna rungu (Effendi, 2006:83). Y dalam hal ini mampu mengatasi penolakan yang diberikan oleh lingkungan sehingga tetap mampu bekerja sama dengan teman yang mau membantu dan menerima keterbatasan subjek.

\section{Sikap sosial}

Salah satu kriteria penyesuaian sosial adalah sikap sosial. Anak harus yang menunjukkan sikap yang menyenangkan terhadap orang lain, terhadap partisipasi sosial, dan terhadap peran kelompok sosial, bila ingin dinilai sebagai orang yang dapat menyesuaikan diri dengan baik secara sosial, bila ingin dinilai sebagai orang yang dapat menyesuaikan diri dengan baik secara sosial (Hurlock, 1980: 287). Sikap sosial yang ditunjukkan Y, A, dan F cukup berbeda. A dan Y sering bercanda dan berkomunikasi dengan teman sedangkan $\mathrm{F}$ lebih suka menyendiri karena merasa terhambat dalam hal berkomunikasi. A dan $\mathrm{Y}$ mampu membina hubungan baik dengan teman di kelas dan mampu mengekspresikan emosi tertekan pada lingkungan yang berbeda dengan cara berusaha untuk berinteraksi dengan teman di kelas. F lebih senang sendiri karena merasa 
lingkungan kurang mampu memahami bahasa. F kurang mampu membina hubungan pribadi dengan teman serta kurang mampu menekan rasa rendah diri terhadap keterbatasan sehingga lebih suka sendiri. Beberapa faktor yang mencerminkan penyesuaian sosial yang efektif, yaitu: Mampu mengekspresikan emosi secara positif dan mempunyai hubungan antar pribadi yang baik (Haber dan Ruyon, 1984:25).

Y, A dan F memiliki kepedulian terhadap teman yang memiliki kesulitan atau memerlukan bantuan. Ketiga subjek mempunyai inisiatif untuk menjenguk teman yang sedang sakit walaupun terkadang terhadang oleh jarak rumah subjek yang jauh dengan teman yang sakit. $\mathrm{Y}$ dan $\mathrm{F}$ juga mau memberikan perhatian ketika teman sedang bersedih namun A sedikit lebih kurang perhatian terhadap lingkungan. $\mathrm{Y}$ akan bertanya penyebab dari kesedihan teman namun subjek tidak berani untuk bertindak lebih jauh sedang $\mathrm{F}$ berusaha untuk menghibur teman subjek yang sedang bersedih ketika berkesempatan dan menganjurkan untuk sabar. F, A, Y memiliki sikap sosial yang tinggi. Y mau peduli, berbagi dan menolong temannya yang mengalami kesulitan. Hal tersebut ditunjukkan bahwa Y mau menunggui temannya yang mencontek pekerjaan rumah miliknya, membantu merapikan dan menyediakan alat praktek untuk teman, membantu teman untuk mencuci alat. F termasuk anak yang cukup peduli pada teman. F mampu berbagi dengan teman. Hal tersebut ditunjukkan melalui perilaku yang muncul seperti mau memberikan contekan pada teman, meminjami teman penghapus dan memberikan perhatian pada teman dengan cara memberikan teman tisu tanpa dimintai terlebih dahulu. A juga mau peduli dan mau berbagi dengan teman. Perilaku peduli dan mau berbagi dapat ditunjukkan melalui perilaku meminjami penghapus dan berbagi buku milik dengan teman. Adanya penjelasan diatas dapat dilihat bahwa ketiga subjek memiliki empati yang baik pada teman sekitar.
Empati merupakan bagian dari kematangan emosi. Emosi memainkan peran penting dalam menentukan cara penyesuaian pribadi dan sosial yang akan dilakukan anak, tidak hanya dalam masa kanak-kanak tetapi juga setelah mereka tumbuh menjadi remaja dan dewasa maka perkembangan emosi individu harus sedemikian rupa sehingga memungkinkan penyesuaian yang baik (Hurlock, 1980:233).

\section{Kepuasan pribadi}

Kepuasan pribadi merupakan salah satu bagian dari penyesuaian sosial yang paling menentukan. Proses untuk menyesuaikan diri dengan baik secara sosial, anak harus merasa puas terhadap kontak sosial dan terhadap peran dimainkan dalam situasi sosial, baik sebagai pemimpin maupun sebagai anggota (Hurlock, 1990). Kepuasan diri sangat penting bagi setiap orang. Remaja tuna rungu dengan keterbatasan yang dimiliki memerlukan adanya dukungan dan bimbing-an untuk mampu memunculkan kepuasan diri. Adanya dukungan dari orang terdekat sangat membantu penyesuaian sosial karena meskipun memiliki motivasi kuat untuk belajar melakukan penyesuaian sosial yang baik, anak tidak mendapatkan bantuan dan bimbingan yang cukup dalam proses belajar ini (Hurlock, 1990). Y dan A memiliki kepuasan diri yang baik. Hal tersebut dapat dilihat adanya keterbatasan yang dimiliki tidak membuat subjek merasa rendah diri. Hal tersebut ditunjukkan melalui hasil wawancara yang menjelaskan bahwa $\mathrm{Y}$ tidak merasa malu dan terganggu dengan kekurangan yang dimiliki dan subjek cuek terhadap lingkungan yang ada sedangkan A tidak merasa malu dengan kekurangan yang dimiliki karena subjek merasa memiliki kelebihan yang tidak dimiliki teman.

Kepuasan pribadi subjek $\mathrm{F}$ berbeda dengan subjek A dan Y. Subjek F sedikit malu dengan kekurangan yang dimiliki namun berusaha menutupi kekurangan dengan mau berkomunikasi dengan orang lain sedangkan $\mathrm{A}$ dan Y tidak merasa malu dan merasa cuek 
dengan keadaan lingkungan. Ketiga subjek memiliki perbedaan dalam memandang keterbatasan yang dimiliki. A dan Y mampu memiliki rasa percaya diri yang tinggi sehingga tidak merasa malu dengan keterbatasan yang dimiliki berbeda dengan $\mathrm{F}$ yang sedikit malu dengan keterbatasan yang dimiliki. Penyesuaian sosial yang efektif juga dicerminkan melalui adanya konsep diri yang positif(Haber dan Ruyon, 1984:25).

Kepuasan diri dipengaruhi oleh adanya kekurangan dan kelebihan oleh subjek. Kelebihan Y yaitu baik, jujur dan bertanggung jawab dan kekurangan $\mathrm{Y}$ adalah cuek dan keras kepala. A memiliki yaitu baik, cantik dan kekurangan yang A miliki yaitu pilih-pilih teman dan sangat tertutup. F memiliki kelebihan yaitu sifat baik, suka menolong dan ramah kekurangan yang dimiliki $\mathrm{F}$ yaitu sulit berkomunikasi dengan teman. Adanya kekurangan dan kelebihan dari masingmasing subjek memperngaruhi proses penyesuaian sosial. Subjek Y cuek hal ini membantu ketika subjek mendapatkan penolakan secara tidak langsung dari lingkungan maka $\mathrm{Y}$ masih mampu untuk menerima keadaan. A memiliki sifat yang sangat tertutup. A hanya mau menceritakan masalah pada ibu bukan teman. Hal ini menjadi sedikit masalah dalam membina relasi sosial yang sehat dan bersahabat dengan teman. A terlihat lebih banyak diam. Sifat tertutup terjadi karena subjek sangat dekat dengan ibu sehingga keakraban lebih diberikan pada orang tua yaitu ibu. A tidak belum mampu memenuhi tugas perkembangan remaja yaitu berusaha melepaskan diri dari ketergantungan emosi terhadap orang tua (Sarwono, 2006:40-41). Namun, secara umum ketiga subjek mampu mengatasi perasaan tertekan dan cemas dalam menghadapi penolakan lingkungan, memiliki konsep diri yang positif karena cukup mampu mengatasi masalah yang ada dan mampu mengekspresikan emosi secara positif (Haber dan Ruyon, 1984:25).

\section{SIMPULAN DAN SARAN}

Berdasarkan hasil penelitian dapat disimpulkan bahwa ketiga subjek mampu melakukan penyesuaian sosial yang cukup efektif. Y mampu melakukan penyesuaian sosial terhadap lingkungan sekolah dengan sangat efektif, A mampu melakukan penyesuaian sosial di sekolah dengan efektif sedangkan F mampu melakukan penyesuaian sosial di sekolah cukup efektif. Hal tersebut ditunjukkan melalui kemampuan para subjek dalam melakukan penyesuaian sosial dengan melihat melalui sembilan kategori yang menjadi fokus penelitian.

Y memiliki penyesuaian sosial di sekolah yang sangat efektif karena setelah dilihat berdasarkan sembilan kategori yang ada subjek sangat mampu melaksanakan seluruh kategori dengan baik walaupun subjek mengalami penolakan dari teman kelas yang tidak mau menerima kekurangan subjek. A mampu melaksanakan penyesuaian sosial dengan efektif. A mampu melaksanakan sembilan kategori walaupun subjek mengalami sedikit masalah terkait dengan ketidakmampuan untuk mengungkapkan perasaan atau bercerita masalah pada teman dekat yang dimana dalam hal ini mempengaruhi kategori membina relasi sosial yang sehat dan bersahabat dengan teman sekelas dan kepuasan diri. Sedangkan F memiliki penyesuaian sosial di sekolah secara cukup efektif karena mampu melaksanakan sembilan kategori walaupun $\mathrm{F}$ memiliki kesulitan dalam berkomunikasi sehingga membuat subjek kesulitan untuk berinteraksi dengan orang sekitar. Hal ini mempengaruhi kategori membina relasi sosial yang sehat dan bersahabat, sikap sosial dan kepuasan diri. F berusaha menutupi keterbatasan subjek dengan cara menampilkan sikap mau berusaha, bersabar dan lebih berjiwa sosial terhadap teman.

Adanya dukungan orang tua dan guru berupa perhatian, bimbingan dan kepercayaan dapat membantu ketiga subjek dalam 
melakukan penyesuaian sosial di sekolah sedangkan pengalaman untuk mendapatkan pendidikan dari sekolah umum sebelumnya tidak sepenuhnya mempengaruhi pembentukan penyesuaian sosial yang efektif.

Dari kesimpulan di atas, peneliti merekomendasikan beberapa usulan dan saran sebagai berikut: pertama, siswa tuna rungu yang bersekolah di sekolah umum diharapkan mampu menekan adanya penolakan dari lingkungan dengan cara menampilkan perilaku positif pada lingkungan serta membentuk gambaran diri mereka yang positif untuk menekan rasa rendah diri atas keterbatasan yang dimiliki; kedua, guru sekolah umum harus mencari informasi dan pengetahuan tentang anak tuna rungu selengkap mungkin sehingga mampu lebih memahami siswa tuna rungu dan mampu untuk lebih bekerja sama dalam mengembangkan dan meminimalisasi hambatan yang dialami oleh siswa tuna rungu di sekolah umum sehingga siswa tidak merasa terkucilkan. Selain itu, sekolah umum yang menerima anak tuna rungu harus memberikan penyuluhan kepada guru tentang penderita tuna rungu sehingga dapat meningkatkan kualitas bakat dan minat siswa tuna rungu di sekolah umum; dan ketiga, orang tua siswa tuna rungu di sekolah umum harus memberi bimbingan berupa perhatian dan dukungan secara maksimal untuk meningkatkan motivasi dan minat siswa tuna rungu sehingga anak lebih berkembang sesuai dengan bakat yang mereka dimiliki.

\section{DAFTAR PUSTAKA}

Delphie, B. (2006). Pembelajaran Anak Berkebutuhan Khusus. Bandung Refika Aditama.

Effendi, M. (2006). Pengantar Psikopedagogik Anak Berkelainan. Jakarta: Bumi Aksara.

Haber, A \& Runyon. (1984). Psychology of adjusment. Homewood: Doorsey Press.

Hurlock, E. (1980). Psikologi Perkembangan. edisi keenam (diterjemahkan Dra. Istiwidayanti dan Drs. Soedjarwo, Msc). Jakarta: PenerbitErlangga

--, E. (1990). Perkembangan Anak jilid 1. edisi keenam (diterjemahkan dr. Med. Meitasari Tjandrasa dan Dra. Muslichah Zarkasih) Jakarta: Penerbit Erlangga.
Sarwono, S. (2006). Psikologi Remaja. Jakarta : PT. Raja Grafindo Persada.

Scheneider, A. (1964). Personal Adjusment and Mental Health. New York : Holt, RineHart and Winston.

Jawa Pos. (22 Januari, 2007). Komitmen Depdiknas terhadap Pendidikan Khusus: Baru Sentuh 21 Persen ABK.

Departemen Pendidikan dan Kebudayaan. (1977). Pendidikan Anak Tuna Rungu, Jakarta : Departemen Pendidikan dan Kebudayaan. 